\title{
Effects of Copper Diffusion in Gallium Arsenide Solar Cells for Space Applications
}

\author{
R.H. van Leest ${ }^{\mathrm{a}, *}$, G.J. Bauhuis ${ }^{\mathrm{a}}$, P. Mulder ${ }^{\mathrm{a}}$, R. van der Heijden ${ }^{\mathrm{b}}$, E. Bongers ${ }^{\mathrm{b}}$, E. Vlieg ${ }^{\mathrm{a}}$, J.J. \\ Schermer $^{\mathrm{a}}$ \\ ${ }^{a}$ Radboud University, Institute of Molecules and Materials, Heyendaalseweg 135, 6525 AJ Nijmegen, The \\ Netherlands \\ ${ }^{b}$ Dutch Space B.V., Mendelweg 30, 2333 CS Leiden, The Netherlands
}

\begin{abstract}
High efficiency, thin-film Epitaxial Lift-Off (ELO) III-V solar cells offer excellent characteristics for implementation in flexible solar panels for space applications. However, the current thin-film ELO solar cell design generally includes a copper handling and support foil. Copper diffusion has a potentially detrimental effect on the device performance and the challenging environment provided by space (high temperatures, electron and proton irradiation) might induce diffusion. It is shown that heat treatments induce copper diffusion. The open-circuit voltage $\left(V_{\mathrm{oc}}\right)$ is the most affected solar cell parameter. The decrease in $\mathrm{V}_{\text {oc }}$ can be explained by enhanced non-radiative recombination via $\mathrm{Cu}$ trap levels in the middle of the band gap. The decrease in $\mathrm{V}_{\mathrm{oc}}$ is found to be dependent on junction depth. In all $\mathrm{Cu}$ cells annealed at $\mathrm{T} \geq 300^{\circ} \mathrm{C}$ signs of $\mathrm{Cu}$ diffusion are present, which implies that a barrier layer inhibiting $\mathrm{Cu}$ diffusion is necessary. Electron radiation damage was found to have no influence on $\mathrm{Cu}$ diffusion.
\end{abstract}

Keywords: III-V Solar Cells, Copper Diffusion, Space Applications, Epitaxial Lift-Off

\section{Introduction}

With the Epitaxial Lift-Off (ELO) technique III-V solar cell structures can be removed from their growth substrates, utilizing a sacrificial $\mathrm{Al}_{\mathrm{x}} \mathrm{Ga}_{1-\mathrm{x}} \mathrm{As}$ layer that can be removed by a selective etch process $[1,2]$. In this way thin, lightweight and flexible solar cells are created, with efficiencies equivalent to or even larger than substrate based solar cells $[3,4,5,6]$. These characteristics make ELO III-V solar cells excellent candidates for implementation in solar panels for space applications [7]. Due to the additional flexibility new light-weight panel designs become available [8] and the launch costs would be reduced due to the lower weight. The ELO process allows for re-use of the expensive GaAs or Ge substrates [3, 9], which would reduce the cost of the cells themselves as well. At the same time the challenging environment provided by space (vacuum, UV irradiation, high energy electron and proton irradiation, temperature cycling) imposes additional challenges in thin-film solar cell design and preparation.

The main potential disadvantage of our current thin-film ELO Gallium Arsenide solar cell design, is that it includes a copper handling and support foil [8]. Copper is notoriously known as a fast diffuser in many semiconductors, including GaAs. It is generally assumed that diffusion of $\mathrm{Cu}$ into a semiconductor device has detrimental effects on the operation of such a device, most

\footnotetext{
${ }^{*}$ Corresponding author

Email address: L.vanLeest@science.ru.nl (R.H. van Leest)
} 
likely because $\mathrm{Cu}$ introduces a trap level in the band gap [10]. Such a trap level is a potential non-radiative recombination pathway $[11,12]$. However, while $\mathrm{Cu}$ diffusion and the effects of $\mathrm{Cu}$ in large semiconductor crystals are described elaborately in literature $[13,14,15,16,17,18,19$, $20,21,22,23,24,25,26,27,28,29]$, there is virtually no literature on the effects of Cu diffusion on semiconductor devices such as solar cells.

The scarce literature available on the device performance under influence of $\mathrm{Cu}$ diffusion may involve deliberate doping of the semiconductor material with $\mathrm{Cu}[30]$ or incorporation of $\mathrm{Cu}$ during preparation of the semiconductor material itself $[31,32,33]$. Such approaches are not useful if one wants to understand what happens when copper (or an other impurity) enters the III-V solar cell material gradually over time. Secondly, there is the issue of material quality. Already in 1974 Hasegawa et. al found that diffusion in large semiconductor crystals is more pronounced than in epitaxial layers [34], most likely due to the better crystal quality of the latter. As material quality of epitaxial GaAs has been strongly improved by the introduction of MOCVD, it may well be that a traditional description of $\mathrm{Cu}$ diffusion in large GaAs crystals is not applicable to a modern MOCVD grown GaAs solar cell.

From the challenging conditions provided by space, the temperature cycles (particularly the higher maximum temperature $70-100^{\circ} \mathrm{C}$ ) are most likely to enhance copper diffusion, as diffusion is known to be strongly temperature dependent [25]. Additionally electron and proton irradiation may also affect copper diffusion, since electron and proton irradiation create defects in the solar cell material [35] and diffusion in large semiconductor crystals is known to depend on interaction with vacancies [16]. Therefore it seems plausible that an increased amount of defects (such as vacancies) enhances $\mathrm{Cu}$ diffusion. UV irradiation and vacuum, the other typical space conditions, are assumed to have no influence on the diffusion process. UV irradiation is expected to affect mainly the protective cover glass and the vacuum is generally associated with delamination issues.

Depending on the exact mission requirements a space solar panel is expected to operate properly for at least 10-15 years in space. This means that for testing purposes the ageing process needs to be accelerated. For irradiation tests the usual approach is to expose solar cells to a dose equivalent to the dose experienced during 15 years in space [36, 35]. But for investigation of temperature effects, there is not such a standard approach. In general elevated temperature accelerated life testing is assumed to be an excellent method to mimic the ageing of a device. It is assumed that operation over a long period of time at a (relatively) low temperature is equal to operation for a much shorter time at a higher temperature. This can be described with an Arrhenius model [37]:

$$
\frac{\mathrm{t}\left(\mathrm{T}_{\mathrm{use}}\right)}{\mathrm{t}\left(\mathrm{T}_{\mathrm{acc}}\right)}=\exp \left[\frac{\mathrm{E}_{\mathrm{a}}}{k}\left(\frac{1}{\mathrm{~T}_{\mathrm{use}}}-\frac{1}{\mathrm{~T}_{\mathrm{acc}}}\right)\right],
$$

in which $\mathrm{T}_{\text {use }}$ is the (average) temperature at which the device will be used and $\mathrm{T}_{\mathrm{acc}}$ is the temperature of the accelerated life test, $k$ is the Boltzmann constant, $\mathrm{E}_{\mathrm{a}}$ is the activation energy and $t\left(T_{\text {use }}\right)$ and $t\left(T_{\text {acc }}\right)$ are the times $t$ at $T_{u s e}$ and $T_{\text {acc }}$ after which the device has reached a predefined amount of degradation.

The main issue with this method is that determination of the activation energy is time consuming and requires a large number of samples, hence there are very few activation energies reported in literature. Nuñez et. al reported an $\mathrm{E}_{\mathrm{a}}$ of $1.02 \mathrm{eV}$ for GaAs concentrator cells [37], which are operated at an elevated working temperature of $65^{\circ} \mathrm{C}$ under concentrated light, this seems a good first estimate for the activation energy. However, the ECSS standard for photovoltaic assemblies and components (ECSS-E-ST-20-08C [38]) advises to calculate the accelerated life test parameters for solar cell assemblies (cell with cover glass, interconnect and by-pass diode) assuming an activation energy of $0.7 \mathrm{eV}$, which would result in higher test temperatures or longer 
test times.

The average working temperature and the time in space depend on the exact type of application of the solar panel. For a LEO (Low Earth Orbit) mission the maximum temperature is $100^{\circ} \mathrm{C}$ and the typical time in orbit is 10 years $\left(0.876 \times 10^{5} \mathrm{~h}\right)$, for a GEO (Geosynchronous Earth Orbit) the maximum temperature is $70^{\circ} \mathrm{C}$ and 15 years $\left(1.314 \times 10^{5} \mathrm{~h}\right)$ in orbit is common practise. With equation 1 accelerated test times $\left(\mathrm{t}\left(\mathrm{T}_{\mathrm{acc}}\right)\right)$ can be calculated. For activation energies of $0.7 \mathrm{eV}$ and $1.02 \mathrm{eV}$ the accelerated test times at various test temperatures are given in table 1 for a GEO mission $\left(15\right.$ years, $\left.70^{\circ} \mathrm{C}\right)$, a LEO mission $\left(10\right.$ years, $\left.100^{\circ} \mathrm{C}\right)$ and an extreme case $(15$ years, $100^{\circ} \mathrm{C}$ ).

Table 1 shows that low test temperatures $\left(200^{\circ} \mathrm{C}\right)$ require test times of many days, which is too time consuming for initial tests. Test times are significantly reduced at high test temperatures $\left(400^{\circ} \mathrm{C}\right)$, but at such temperatures the induced damage might not be related to $\mathrm{Cu}$ diffusion (alone). Diffusion processes depend exponentially on temperature so at higher temperatures other diffusion processes might start to play a significant role as well. For example dopant diffusion (particularly $\mathrm{Zn}$ ) and gold diffusion. Any of this additional diffusion damage should be observed for all GaAs solar cells regardless of the metals present in the contact. Since we observe some damage to cells with plain gold contacts at $400^{\circ} \mathrm{C}$ (see section 3.2 ) we took this as a maximum temperature to be used. Ideally a temperature somewhere in between (as low as possible) should be used. With the $1.02 \mathrm{eV}$ activation energy all three scenarios (GEO, LEO, extreme) are covered with $4 \mathrm{~h}$ at $300^{\circ} \mathrm{C}$, hence it was assumed to be a suitable first test. If no diffusion effects are observed the test can easily be extended to a few days in order to cover all scenarios with an activation energy of $0.7 \mathrm{eV}$.

In order to check whether Cu-foil based ELO thin-film GaAs solar cells are suited for applications in space, it is important to gain more understanding of the effects that exposure to the space environment will have on $\mathrm{Cu}$ diffusion in GaAs solar cells. In preparatory experiments which will be described in paragraph 3.1, it was found that ELO cells are not suited for heat treatments at temperatures $\geq 250^{\circ} \mathrm{C}$. However, lower temperatures require annealing times of many days (see table 1) in order to simulate 15 years in space. Therefore regular substrate based GaAs solar cells were used to investigate the effects of $\mathrm{Cu}$ diffusion on the cell performance. In order to do so the substrate cell structures were adapted to provide a geometry that closely resembles that of ELO cells. This is a valid alternative since copper diffusion is dependent on the material [25], which is GaAs for both thin-film and substrate-based solar cells and the material quality [34], which is equal as both types of structures are grown by the same MOCVD process and perform equally well [4]. For final qualification of ELO thin-film solar cells actual thin-film structures should be used, but for study of potentially damaging processes substrate-based alternatives can be used as long as the studied process is not expected to be dependent on the thin-film nature of the ELO cells.

A standard ELO thin-film $(\sim 2 \mu \mathrm{m})$ GaAs solar cell (see figure 1a) is typically produced with $\mathrm{a} \sim 100 \mathrm{~nm}$ gold back contact and a $\sim 15 \mu \mathrm{m}$ copper handling and support foil. Copper was chosen because it is cheap and compatible with all post-ELO processing steps and allows for easy contacting of the solar cell. Simply applying a similar contact scheme at the back of a substrate solar cell (see figures $1 \mathrm{~b}$ and 1c) would not be representative for the ELO cell configuration, as the copper would have to diffuse through $\sim 300 \mu \mathrm{m}$ of GaAs before reaching the cell (which has a thickness of only a few $\mu \mathrm{m}$ ). Thus the copper has to be applied on the front contact (thick layer of $\mathrm{Cu}$ on thin $\mathrm{Au}$ contact). Normally the front contact only covers a few percent of the solar cell surface, which is clearly different from a completely covered back surface. On the other hand it is also not possible to cover the front of the cell completely, because then light can no longer enter the cell and hence there would be no working device that can be tested. As a compromise 
between these two extremes a front contact grid pattern with nearly $50 \%$ coverage was designed (see figure 2), allowing both sufficient covering with $\mathrm{Cu}$ and proper operation of the solar cell.

In order to distinguish between the effects related to the presence of $\mathrm{Cu}$ and other effects a reference without copper is necessary. For the ELO thin-film cells this would be difficult as replacement of the $\mathrm{Cu}$ handling foil with $\mathrm{Au}$ would be expensive and replacement with another metal may cause problems during post-ELO processing or the metal may also cause diffusion effects. This also explains why replacement of copper with another metal is not the most favourable solution in the first place. As substrate cells are normally prepared without copper anyway, there is no problem in preparing cells with and without copper on the gold front contacts.

In this study we investigate the effect of heat treatments and electron irradiation on $\mathrm{Cu}$ diffusion in GaAs solar cells. Commercial substrate based solar cells typically have a shallow junction (see figure 1b, $p$ - $n$ junction close to the front surface of the cell), therefore a cell structure with the junction at $75 \mathrm{~nm}$ from the window was chosen as a reference system. Since the introduction of $(\mathrm{Cu})$ trap levels is anticipated to be particularly harmful in the depletion region around the $p-n$ junction, a dependence of copper diffusion on junction depth is expected, therefore also deep junction cells (see figure 1c, $p$ - $n$ junction further away from the front surface) with junction depths of 500, 1000 and 2000nm were investigated.

It should be noted that in a thin-film ELO cell the copper is applied at the back of the cell and the copper is thus closer to the junction in a deep junction ELO cell than in a shallow junction ELO cell. In the substrate cells used in the experiments described in this paper the copper is closer to the junction in shallow junction solar cells.

\section{Material and methods}

The solar cell structures were grown in an Aixtron 200 MOCVD reactor on 2 inch Zn-doped p-type GaAs substrates (( $\left.\begin{array}{lll}1 & 0 & 0\end{array}\right) 2^{\circ}$ off towards $\left.\left[\begin{array}{lll}1 & 1 & 0\end{array}\right]\right)$. Four different substrate solar cell structures were prepared, a shallow junction type (structure in figure $1 \mathrm{~b}$ ) with a $p$ - $n$ junction depth of $75 \mathrm{~nm}$, and three deep junction types (structure in figure 1c) with $p$ - $n$ junction depths of $500 \mathrm{~nm}, 1000 \mathrm{~nm}$ and $2000 \mathrm{~nm}$. On top of the $p$-type substrate a $300 \mathrm{~nm}$ Zn-doped $p$-GaAs contact layer was grown and a $75 \mathrm{~nm} \mathrm{Zn}$ - doped $p$-InGaP back surface field (BSF). The active solar cell structure is $2000 \mathrm{~nm}$ of Zn-doped $p$-type GaAs and $75 \mathrm{~nm}$ Si-doped $n$-type GaAs for the shallow junction sample; and 100nm of Zn-doped $p$-GaAs and 500, 1000 or 2000nm Si doped $n$-GaAs for the deep junction samples. On top of the active $p$ - $n$ junction a $30 \mathrm{~nm}$ Si doped $n$-AlInP window and a $300 \mathrm{~nm}$ Te-doped $n$-GaAs contact layer were grown.

After growth a front contact of either $\mathrm{Au}(100 \mathrm{~nm})$ or $\mathrm{Au}(100 \mathrm{~nm}) / \mathrm{Cu}(500 \mathrm{~nm})$ was applied by e-beam evaporation. Plain gold contacts can be used if the doping level in the contact layer is sufficiently high (in this case $1.7 \times 10^{19} \mathrm{~cm}^{-3}$ for the $n$-GaAs contact layer and $3.0 \times 10^{17} \mathrm{~cm}^{-3}$ for the $p$-GaAs contact layer). A grid pattern with a cell coverage of nearly $50 \%$ was used (see figure 2). After the evaporation of the front contact, $6 \times 6 \mathrm{~mm}$ cells were created by a MESA etch. Then a $100 \mathrm{~nm}$ Au back contact was applied by e-beam evaporation. After application of the back contact the GaAs contact layer was removed between the grid fingers of the front contact. Finally a $\mathrm{ZnS}(42.5 \mathrm{~nm}) / \mathrm{MgF}_{2}(88.0 \mathrm{~nm})$ anti-reflection coating was applied by e-beam evaporation. Henceforth cells with standard Au contacts will be referred to as gold or Au cells and cells with $\mathrm{Cu}$ on top of the $\mathrm{Au}$ front contact will be referred to as copper or $\mathrm{Cu}$ cells.

Also a set of shallow junction ELO cells was prepared with a $\sim 20 \mu \mathrm{m}$ thick Au back contact and a 250nm Au front contact. These samples will be referred to as Au ELO cells. The other cell specifications are the same as for the $75 \mathrm{~nm}$ shallow junction substrate cells. 
Most anneal experiments were performed for $4 \mathrm{~h}$ in a tube furnace with a specially designed quartz inner tube that allowed for in-tube temperature measurements and the inlet of a gas $\left(\mathrm{N}_{2}\right)$ to create an inert atmosphere. Incidentally cells were also annealed for shorter periods of time in a rapid thermal annealing furnace with a $\mathrm{N}_{2}$ atmosphere.

Using the tube furnace sets of $\mathrm{Au}$ substrate cells and $\mathrm{Cu}$ substrate cells were simultaneously given an anneal treatment. The annealing time was 4 hours and the temperature was varied around $300^{\circ} \mathrm{C}$. The higher temperature was chosen based on the amount of damage observed at $300^{\circ} \mathrm{C}$. In this way the $75 \mathrm{~nm}$ junction cells were annealed at 275,300 or $325^{\circ} \mathrm{C}$, the $500 \mathrm{~nm}$ junction cells at 250,300 or $350^{\circ} \mathrm{C}$ and the 1000 and $2000 \mathrm{~nm}$ junction cells at 200,300 or $400^{\circ} \mathrm{C}$. The ELO Au cells were only subjected to an anneal treatment of 4 hours at $300^{\circ} \mathrm{C}$ in total.

In addition sets of $75 \mathrm{~nm}$ junction $\mathrm{Au}$ and $\mathrm{Cu}$ cells on substrate (structure in figure 1b) were simultaneously exposed to a $1 \mathrm{MeV}$ electron irradiation dose of $10^{15} \mathrm{e}^{-} / \mathrm{cm}^{2}$, which is equivalent to the dose encountered during 15 years in space on a GEO mission. After exposure the cells were characterized again. Then the effect of an anneal treatment on the irradiated cells was tested. The electron irradiated cells were annealed for $4 \mathrm{~h}$ at $275^{\circ} \mathrm{C}$, this temperature was chosen based on the results of the experiments on cells with different junction depths. A similar experiment was done with non-irradiated $75 \mathrm{~nm}$ junction $\mathrm{Au}$ and $\mathrm{Cu}$ cells. The anneal treatment (4h at $275^{\circ} \mathrm{C}$ ) was repeated $5 \mathrm{x}$ (total annealing time $20 \mathrm{~h}$ ) for both irradiated and non-irradiated $75 \mathrm{~nm}$ junction $\mathrm{Au}$ and $\mathrm{Cu}$ cells.

Before and after each anneal or radiation treatment the solar cells were characterized by measuring illuminated J-V curves $\left(25^{\circ} \mathrm{C}\right.$, AM1.5), dark J-V curves and External Quantum Efficiencies (EQE). From the J-V curves before and after annealing (or electron irradiation) the solar cell parameters $\mathrm{J}_{\mathrm{sc}}, \mathrm{V}_{\mathrm{oc}}$ and Fill Factor $(\mathrm{FF})$ were determined. By dividing the value after annealing by the value before annealing, remaining factors for these parameters were obtained and these values were averaged for each set of 4 cells (for example $475 \mathrm{~nm}$ junction Au cells annealed for 4 h at $300^{\circ} \mathrm{C}$ ).

Additionally infra-red electroluminescence images were captured for non-annealed and annealed cells of all junction depths. A bias voltage of $1.155 \mathrm{~V}$ was used and an exposure time of $0.01 \mathrm{~s}$. All forms of exposure correction were turned off and lighting conditions in the room were kept as constant as possible.

\section{Results \& Discussion}

\subsection{ELO cells}

In figure 3 the $\mathrm{J}-\mathrm{V}$ curves of $\mathrm{Au}$ ELO cells before and after annealing for $4 \mathrm{~h}$ at $300^{\circ} \mathrm{C}$ are plotted, for comparison the curves of $\mathrm{Au}$ deep junction (2000nm) substrate cells before and after annealing under the same conditions are plotted as well. The substrate cell shows a slight decrease in both $\mathrm{J}_{\mathrm{sc}}$ and $\mathrm{V}_{\mathrm{oc}}$ and a small increase in series resistance. The ELO cells show a similar slight decrease in $\mathrm{J}_{\mathrm{sc}}$ and a significant decrease of $\mathrm{V}_{\mathrm{oc}}$. This means that the ELO cells degrade significantly even without the presence of $\mathrm{Cu}$. ELO Au cells are thus not suited for accelerated ageing tests under these conditions. At an annealing temperature of $250^{\circ} \mathrm{C}$ the decrease in $\mathrm{V}_{\mathrm{oc}}$ is less than for $300^{\circ} \mathrm{C}$ (Remaining factors of $\mathrm{V}_{\mathrm{oc}}$ are 0.929 and 0.867 respectively), but the decrease is still significantly larger than for the $\mathrm{Au}$ substrate cells at $300^{\circ} \mathrm{C}$ (Remaining factor $\mathrm{V}_{\mathrm{oc}} 0.972$ ). This shows that annealing temperatures $\geq 250^{\circ} \mathrm{C}$ are not suited for accelerated life tests with ELO solar cells.

Similar experiments with $\mathrm{Cu}$ ELO and 2000nm deep junction $\mathrm{Cu}$ substrate cells show that the damage to the $\mathrm{Cu}$ ELO cells is larger than for the $\mathrm{Cu}$ substrate cells at an annealing temperature of $300^{\circ} \mathrm{C}$ (average $\mathrm{V}_{\text {oc }}$ remaining factors of 0.338 and 0.950 for ELO and substrate cells 
respectively), but that the damage at $200^{\circ} \mathrm{C}$ is comparable (average $\mathrm{V}_{\mathrm{oc}}$ remaining factors of 1.001 and 0.989 for ELO and substrate cells respectively). Therefore any accelerated life tests with ELO cells should be done at temperatures $\leq 200^{\circ} \mathrm{C}$. However, from a practical point of view lowering of the annealing temperature further to $200^{\circ} \mathrm{C}$ or less is not an option as the annealing time then needs to be increased to many days to be relevant for the anticipated application (see table 1). Therefore further experiments were performed with substrate cells rather than with thin-film ELO cells.

The most probable explanation for the larger observed damage of the ELO cells is the difference in thermal expansion coefficient between GaAs $\left(5.4^{*} 10^{-6} \mathrm{~K}^{-1}\right)$ on the one hand and copper $\left(16.5^{*} 10^{-6} \mathrm{~K}^{-1}\right)$ and gold $\left(14.2^{*} 10^{-6} \mathrm{~K}^{-1}\right)$ on the other hand. This difference is likely to induce stress and possibly even cracks and defects in the thin-film, which also diminishes solar cell performance.

\subsection{Influence of Junction Depth}

From the $\mathrm{J}-\mathrm{V}$ measurements before and after the annealing experiments the $\mathrm{J}_{\mathrm{sc}}, \mathrm{V}_{\mathrm{oc}}$ and Fill Factor remaining factors were obtained. The average $\mathrm{J}_{\mathrm{sc}}$ remaining factors are plotted in figure $4 \mathrm{a}$ and the average $\mathrm{V}_{\mathrm{oc}}$ remaining factors in figure $4 \mathrm{~b}$. Significant changes in $\mathrm{J}_{\mathrm{sc}}$ of more than $2 \%$ are only observed for some deep junction cells after annealing at $400^{\circ} \mathrm{C}$. A decrease in $\mathrm{V}_{\mathrm{oc}}$ is observed for all cells annealed at $\mathrm{T} \geq 300^{\circ} \mathrm{C}$, the changes are larger for $\mathrm{Cu}$ cells of all junction depths and are more severe for the 75 and $500 \mathrm{~nm}$ junction cells. The changes in fill factor show trends similar to those of the $\mathrm{V}_{\mathrm{oc}}$ and are therefore not plotted.

The most significant change (a decrease of almost 10\%) in $\mathrm{J}_{\mathrm{sc}}$ is observed for the 2000nm junction $\mathrm{Cu}$ cells annealed at $400^{\circ} \mathrm{C}$. A decrease in $\mathrm{J}_{\mathrm{sc}}$ is related to a decrease in collection efficiency. In general the collection efficiency is reduced due to the fact that less minority carriers reach the $p-n$ junction. In the case of $\mathrm{Cu}$ diffusion in a deep junction solar cell, a plausible explanation is that $\mathrm{Cu}$ introduces defects mainly in the top part of the solar cell, these defects act as recombination centres, reducing the minority carrier lifetime. Since the distance to the $p$ - $n$ junction is large, this reduces the chance that minority carriers reach the junction and contribute to the current of the solar cell. This is confirmed by the data in figure $4 \mathrm{a}$, which show that this effect is most pronounced in the $2000 \mathrm{~nm} \mathrm{Cu}$ cells annealed at $400^{\circ} \mathrm{C}$ in which $\mathrm{Cu}$ is expected to have penetrated the cell the furthest and the distance from the average photon absorption cite to the $p$ - $n$ junction is largest.

This can also be confirmed by EQE measurements, from which by integration over the spectrum $\mathrm{J}_{\mathrm{sc}}$ can be obtained. The $2000 \mathrm{~nm}$ deep junction $\mathrm{Cu}$ cells annealed at $400^{\circ} \mathrm{C}$ are the only cells that show a change in EQE curve, as could be expected from the $\mathrm{J}_{\mathrm{sc}}$ remaining factors plotted in figure 4a. In figure 5 EQE curves before and after annealing for $4 \mathrm{~h}$ at $400^{\circ} \mathrm{C}$ are plotted for 2000nm Au and $\mathrm{Cu}$ samples. It can be seen that while the EQE curve of the Au cell does not change upon annealing, the EQE of the $\mathrm{Cu}$ cell is significantly lower after annealing. The EQE of the $\mathrm{Cu}$ cell is lower over the whole wavelength range, but the difference is largest at lower wavelengths. Lower wavelengths correspond to higher energy photons which are absorbed closer to the surface of the solar cell, this suggests that the reduced cell performance is indeed caused by reduced collection efficiency of minority carriers created in the top part of the solar cell.

In figure $4 \mathrm{~b}$ the average $\mathrm{V}_{\mathrm{oc}}$ remaining factors of $\mathrm{Au}$ and $\mathrm{Cu}$ cells with different junction depths are plotted as a function of annealing temperature. The $\mathrm{Cu} 75$ and 500nm junction cells show a strong decrease at annealing temperatures of $300^{\circ} \mathrm{C}$ and higher, all $\mathrm{Au}$ cells and the $\mathrm{Cu} 1000 \mathrm{~nm}$ and 2000nm junction cells show a slight decrease at these annealing temperatures. The decrease 
at annealing temperatures below $300^{\circ} \mathrm{C}$ is negligible. This indicates a decrease in $\mathrm{V}_{\mathrm{oc}}$ for all cells after annealing, but that it is particularly strong for $\mathrm{Cu}$ cells with the smallest junction depths.

Since $\mathrm{V}_{\mathrm{oc}} \approx \frac{k T}{q} \ln \left(\frac{\mathrm{J}_{\mathrm{sc}}}{\mathrm{J}_{0}}\right)$ (in which $\mathrm{J}_{0}$ is the dark saturation current)[11] and the fact that no significant change in $\mathrm{J}_{\mathrm{sc}}$ is observed for the $\mathrm{Cu} 75$ and $500 \mathrm{~nm}$ junctions, the change in $\mathrm{V}_{\mathrm{oc}}$ must be caused by an increase in $\mathrm{J}_{0}$. The most likely cause of such a decrease in $\mathrm{V}_{\mathrm{oc}}$ is an increase in non-radiative recombination. Non-radiative recombination via trap levels in the depletion region is known to affect $\mathrm{V}_{\mathrm{oc}}$ and $\mathrm{Cu}$ is known to introduce such a trap level [10]. Since the effect is more pronounced in $\mathrm{Cu}$ cells and particularly in the $75 \mathrm{~nm}$ and 500nm junction cells in which the copper is expected to reach the junction first, it seems plausible that in-diffused copper has introduced trap levels in the depletion region.

Since we defined $4 \mathrm{~h}$ at $300^{\circ} \mathrm{C}$ as a minimum the solar cells should be able to cope with, it is interesting to compare the $\mathrm{J}_{\mathrm{sc}}$ and $\mathrm{V}_{\mathrm{oc}}$ remaining factors after annealing under these conditions for the different junction depths. In figure 6 the average $\mathrm{J}_{\mathrm{sc}}$ and $\mathrm{V}_{\mathrm{oc}}$ remaining factors are plotted versus junction depth for both $\mathrm{Au}$ and $\mathrm{Cu}$ cells. From this figure it is clear that the change in $\mathrm{J}_{\mathrm{sc}}$ is negligible at this temperature and that there is no significant difference between the Au and $\mathrm{Cu}$ cells. At the same time the $\mathrm{V}_{\text {oc }}$ decreases for both $\mathrm{Au}$ and $\mathrm{Cu}$ cells of all junction depths. The change is significantly larger for the $\mathrm{Cu}$ cells, this suggests that regardless of junction depth copper introduces trap levels that can act as a non-radiative recombination pathway. The fact that for the smallest junction depths the decrease in $\mathrm{V}_{\mathrm{oc}}$ remaining factor is largest suggests that the $\mathrm{Cu}$ traps are particularly efficient in the vicinity of the depletion region, as the copper should have diffused equally far into all $\mathrm{Cu}$ cells.

In figure 7 dark $\mathrm{J}-\mathrm{V}$ curves of $75 \mathrm{~nm} \mathrm{Au}, 75 \mathrm{~nm} \mathrm{Cu}, 2000 \mathrm{~nm} \mathrm{Au}$ and 2000nm Cu cells before and after annealing at $300^{\circ} \mathrm{C}$ are plotted. From the position and shape of the curves it can readily be deduced that the dark current increases for all cells. The largest increase in dark current is observed for the $75 \mathrm{~nm}$ junction $\mathrm{Cu}$ cell, while the changes for both $\mathrm{Au}$ cells and the 2000nm $\mathrm{Cu}$ cell are relatively small. This is in accordance with the changes in $\mathrm{V}_{\text {oc }}$ depicted in figure 6 .

Electroluminescence was used to visualize the presence of non-radiative recombination centres in the solar cells. The pictures appear less bright if non-radiative recombination increases. Independent of the junction depth, the electroluminescence images of the Au cells annealed at $300^{\circ} \mathrm{C}$ shown in figure 8 appear to show more or less the same brightness. On the other hand, the $\mathrm{Cu}$ cells show a gradual darkening as the junction depth decreases. Indicating an increase in non-radiative recombination. The observed decrease in radiative recombination is in agreement with the changes in $\mathrm{V}_{\text {oc }}$ shown in figure 6 .

From the other electroluminescence images (not shown here) it appears that the Au cells all have a similar luminescent intensity, regardless of the junction depth or annealing temperature. The same is true for the non-annealed $\mathrm{Cu}$ cells and for the $\mathrm{Cu}$ cells annealed at the lowest temperatures $\left(200,250\right.$ or $\left.275^{\circ} \mathrm{C}\right)$, but for the $75 \mathrm{~nm}$ cells annealed at $325^{\circ} \mathrm{C}$ and the $500 \mathrm{~nm}$ cells annealed at $350^{\circ} \mathrm{C}$ no luminescence is observed and the 1000 and $2000 \mathrm{~nm} \mathrm{Cu}$ cells annealed at $400^{\circ} \mathrm{C}$ appear to be less bright. This is in accordance with the observed decreases in $\mathrm{V}_{\mathrm{oc}}$ in figure $4 \mathrm{~b}$.

We expect that the $\mathrm{J}_{\mathrm{sc}}$ of the solar cells will not change significantly during the operational life time in space, but a decrease in $\mathrm{V}_{\text {oc }}$ is to be anticipated. For $\mathrm{Au}$ cells the change is relatively small and is not expected to be an issue, but the presence of $\mathrm{Cu}$ proves to be a risk for the solar cell performance, particularly if the distance between copper and $p-n$ junction is small. Hence the application of a diffusion barrier, to prevent copper diffusion in thin-film ELO cells is thought to be a necessary precaution. In the search for a suitable barrier layer the $V_{o c}$ is 
the most important parameter to monitor, as this is the first parameter to change upon copper diffusion.

\subsection{Electron Radiation Effects}

For the $75 \mathrm{~nm}$ shallow junction type solar cells the effect of electron radiation was investigated. The J-V curves of $75 \mathrm{~nm}$ junction $\mathrm{Au}$ and $\mathrm{Cu}$ cells before and after irradiation with a dose of $10^{15}$ $\mathrm{e}^{-} / \mathrm{cm}^{2} 1 \mathrm{MeV}$ electrons are plotted in figure $9 \mathrm{a}$ and the EQE curves in figure $9 \mathrm{~b}$. In both graphs the curves of both $\mathrm{Au}$ and $\mathrm{Cu}$ cells before irradiation overlap and the curves of both $\mathrm{Au}$ and $\mathrm{Cu}$ cells after irradiation overlap also, but they are at a significantly lower level than the curves before irradiation. The fact that both $\mathrm{Au}$ and $\mathrm{Cu}$ cells are affected in the same way indicates that electron irradiation itself does not induce copper diffusion.

The $\mathrm{J}-\mathrm{V}$ curves in figure $9 \mathrm{a}$ show a decrease in both $\mathrm{J}_{\mathrm{sc}}$ and $\mathrm{V}_{\mathrm{oc}}$, with the relative decrease in $\mathrm{V}_{\mathrm{oc}}$ being larger than the decrease in $\mathrm{J}_{\mathrm{sc}}$. The change in $\mathrm{J}_{\mathrm{sc}}$ is also clear from the EQE curves in figure $9 \mathrm{~b}$, here a decrease is visible from $\sim 650 \mathrm{~nm}$ to the wavelength corresponding to the band gap, which indicates that the induced damage occurs relatively deep in the solar cells, since low energy photons are absorbed deep in the solar cell. These effects on the J-V and EQE curves are similar to those for the middle GaAs cell of a triple junction solar cell observed by Brandt et. al [35], the somewhat larger damage we observe is probably related to the fact that we tested the effect of irradiation without a cover glass and to the fact that no radiation hard design was used.

It is known that annealing treatments can reduce the damage of electron irradiation [35], but at the same time anneal treatments also enhance $\mathrm{Cu}$ diffusion. Hence we investigated the effect of anneal treatments on irradiated cells and compared it to the effect of the same anneal treatment on non-irradiated cells. Since after $4 \mathrm{~h}$ at $300^{\circ} \mathrm{C}$ a significant decrease in $\mathrm{V}_{\mathrm{oc}}$ is already visible for the $75 \mathrm{~nm}$ junction cells, but not yet after $4 \mathrm{~h}$ at $275^{\circ} \mathrm{C}$ (see section 3.2 , figure $4 \mathrm{~b}$ ), it was chosen to anneal at $275^{\circ} \mathrm{C}$ in steps of $4 \mathrm{~h}$ to see whether the decrease in $\mathrm{V}_{\text {oc }}$ starts at different points for irradiated and non-irradiated $\mathrm{Cu}$ cells and whether or not this decrease is also observed for $\mathrm{Au}$ cells.

In figure $10 \mathrm{a}$ the average $\mathrm{J}_{\mathrm{sc}}$ remaining factors are plotted versus annealing time at $275^{\circ} \mathrm{C}$ for irradiated and non-irradiated $\mathrm{Au}$ and $\mathrm{Cu}$ cells. Only before the annealing treatments a significant difference is visible as the irradiated cells have a lower starting point (due to the lower $\mathrm{J}_{\mathrm{sc}}$ caused by the electron irradiation). After $4 \mathrm{~h}$ at $275^{\circ} \mathrm{C}$ all remaining factors are virtually 1 and this does not change upon subsequent annealing steps. Thus an annealing step of $4 \mathrm{~h}$ at $275^{\circ} \mathrm{C}$ is able to restore the $\mathrm{J}_{\mathrm{sc}}$ of both irradiated $\mathrm{Au}$ and irradiated $\mathrm{Cu}$ cells.

Different trends are observed for the average $\mathrm{V}_{\mathrm{oc}}$ remaining factor, as is visible in figure $10 \mathrm{~b}$. Again the irradiated cells have a lower starting point than the non-irradiated cells due to the radiation damage. After annealing different effects are visible for all four types of cells. The non-irradiated Au cells are virtually not affected by the heat treatment. The irradiated Au cells show an increase in the remaining factor after the first annealing treatment but the $V_{\text {oc }}$ is not restored to its original value. The remaining factor remains steady during subsequent anneal treatments. The non-irradiated $\mathrm{Cu}$ cells show a slight decrease after the first anneal treatment, then the $\mathrm{V}_{\mathrm{oc}}$ remaining factor remains steady during another two anneal treatments and after $16 \mathrm{~h}$ at $275^{\circ} \mathrm{C}$ the remaining factor starts to decrease rapidly. Finally the irradiated $\mathrm{Cu}$ cells show an increase after the first anneal treatment, similar to the one observed for irradiated Au cells, the remaining factor remains steady for the next $12 \mathrm{~h}$ and then starts to decrease rapidly after $16 \mathrm{~h}$ at $275^{\circ} \mathrm{C}$, just like for the non-irradiated $\mathrm{Cu}$ cells.

The electron irradiation experiments show that $\mathrm{Au}$ and $\mathrm{Cu}$ cells are affected in the same way by an irradiation treatment. Subsequent annealing treatments are able to restore the $\mathrm{J}_{\mathrm{sc}}$ completely 
and to partially restore the $\mathrm{V}_{\mathrm{oc}}$, the effect is similar for both $\mathrm{Au}$ and $\mathrm{Cu}$ cells. In the end decrease in $\mathrm{V}_{\mathrm{oc}}$ due to copper diffusion occurs after the same annealing time for both irradiated and nonirradiated $\mathrm{Cu}$ cells, indicating that the temperature causes diffusion and that radiation damage does not influence this.

\section{Conclusions \& Outlook}

The aim of this study was to investigate whether thin-film ELO solar cells on a $\mathrm{Cu}$ foil carrier/back contact can directly be applied in space solar panels. Since ELO thin-film cells were found to be unsuited for accelerated ageing tests at temperatures above $200^{\circ} \mathrm{C}$, a model system of GaAs substrate solar cells was used to test the effects of the space environment on copper diffusion. The effect of heat treatments on $\mathrm{Cu}$ diffusion was studied for cells with and without $\mathrm{Cu}$ for four different junction depths (75, 500, 1000 and 2000nm).

It is demonstrated that the $\mathrm{J}_{\mathrm{sc}}$ of the cells remains more or less unaffected, but that the $\mathrm{V}_{\mathrm{oc}}$ of the $\mathrm{Cu}$ cells is reduced after annealing. Because diffusion is strongly temperature dependent the effect is most apparent for the smallest junction depths (75 and 500nm) and at the highest annealing temperatures $\left(325,350,400^{\circ} \mathrm{C}\right)$. The decrease in $\mathrm{V}_{\mathrm{oc}}$ can be explained by enhanced non-radiative recombination, via $\mathrm{Cu}$ trap levels in the middle of the band gap. The fact that the effect is more pronounced for the shorter junction depths, suggest that these traps are particularly harmful if they are introduced in or near the depletion region around the $p$ - $n$ junction. This is supported by a related increase in $\mathrm{J}_{0}$, which was visualized with electroluminescence imaging and dark J-V measurements.

For the $75 \mathrm{~nm}$ junction depth the effect of electron irradiation and subsequent heat treatments were investigated. It is found that electron radiation affects $\mathrm{Au}$ and $\mathrm{Cu}$ cells in the same manner. Annealing reduces the damage caused by the exposure to electron irradiation. A significant and similar decrease in $\mathrm{V}_{\mathrm{oc}}$ is observed for both irradiated and non-irradiated $\mathrm{Cu}$ cells after $16 \mathrm{~h}$ annealing at $275^{\circ} \mathrm{C}$, which implies that $\mathrm{Cu}$ diffusion is solely dependent on the heat treatment and is not affected by damage caused by electron radiation.

It is shown that only heat treatments induce copper diffusion and that $\mathrm{V}_{\mathrm{oc}}$ is the solar cell parameter that is most affected by it. $\mathrm{J}_{\mathrm{sc}}$ is only affected for deep junction samples annealed at $400^{\circ} \mathrm{C}$, while a decrease in $\mathrm{V}_{\text {oc }}$ is observed for all $\mathrm{Cu}$ cells after $4 \mathrm{~h}$ at $300^{\circ} \mathrm{C}$, which was set as the minimum the solar cells should be able to cope with. These results imply that application of a diffusion barrier or implementation of an alternative metal foil carrier/back contact is necessary and that the $\mathrm{V}_{\mathrm{oc}}$ is the best indicator of $\mathrm{Cu}$ diffusion.

The prime alternatives for a different metal foil carrier known to be compatible witg thinfilm cell processing are silver and gold, which are much more expensive than copper. Other alternatives such as molybdenum have to be tested for their applicability and compatibility with thin-film cell processing and are therefore not a desired solution. Alternatively a diffusion barrier [39] can be applied, this is a thin layer of material that either slows down the diffusion process or inhibits diffusion completely. For silicon numerous potential diffusion barriers are reported, but of particular interest for implementation in GaAs solar cells would be the electroplated titanium [40] and nickel [41, 42, 43, 44] diffusion barriers suggested for silicon solar cells. Recently copper metallization schemes for III-V solar cells have been suggested [45, 46], it is of interest to see whether these can block or inhibit copper diffusion. Finally compound barriers such as metal nitrides are of interest, generally their diffusion blocking properties are excellent, but their low conductivity and high melting points provide new challenges in device fabrication. 


\section{Acknowledgements}

The authors acknowledge financial support from the Netherlands Space Office (NSO) under project number PEP12010 and the technical support provided by Mr W. Corbeek.

\section{References}

[1] M. M. A. J. Voncken, J. J. Schermer, A. T. J. van Niftrik, G. J. Bauhuis, P. Mulder, P. K. Larsen, T. P. J. Peters, B. de Bruin, A. Klaassen, J. J. Kelly, Etching AlAs with HF for epitaxial lift-off applications, J. Electrochem. Soc. 151 (2004) G347.

[2] A. T. J. van Niftrik, J. J. Schermer, G. J. Bauhuis, P. Mulder, P. K. Larsen, J. J. Kelly, A diffusion and reaction related model of the epitaxial lift-off process, J. Electrochem. Soc. 154 (2007) D629.

[3] R. Tatavarti, G. Hillier, A. Dzankovic, G. Martin, F. Tuminiello, R. Navaratnajarah, G. Du, D. P. Vu, N. Pan, Lightweight, low cost GaAs solar cells on 4" epitaxial lift-off (ELO) wafers, in: 33rd IEEE Photovoltaics Specialists Conference, 2008, pp. 1-4.

[4] G. J. Bauhuis, P. Mulder, E. J. Haverkamp, J. C. C. M. Huijben, J. J. Schermer, 26.1\% thin-film GaAs solar cell using epitaxial lift-off, Sol. Energy Mater. Sol. Cells 93 (2009) 1488-1491.

[5] B. M. Kayes, H. Nie, R. Twist, S. G. Spruytte, F. Reinhardt, I. C. Kizilyalli, G. S. Higashi, 27.6\% Conversion efficiency, a new record for single-junction solar cells under 1 sun illumination, in: Proceedings of the 37th IEEE Photovoltaics Specialists Conference, 2011.

[6] O. D. Miller, E. Yablonovitch, S. R. Kurtz, Strong Internal and External Luminescence as Solar Cells Approach the Shockley-Queisser Limit, IEEE J. Photovolt. 2 (2012) 303-311.

[7] J. J. Schermer, P. Mulder, G. J. Bauhuis, P. K. Larsen, G. Oomen, E. Bongers, Thin-film GaAs Epitaxial Lift-off Solar Cells for Space Applications, Prog. Photovolt. Res. Appl. 13 (2005) 587-596.

[8] J. Feenstra, N. J. Smeenk, P. Mulder, G. Oomen, E. Vlieg, J. J. Schermer, Flexible shielding layers for solar cells in space applications, to be published (2015).

[9] G. J. Bauhuis, P. Mulder, E. J. Haverkamp, J. J. Schermer, E. Bongers, W. Köstler, G. Strobl, Wafer reuse for repeated growth of III-V solar cells, Prog. Photovolt. Res. Appl. $2010(2010) 1-5$.

[10] S. M. Sze, J. C. Irvin, Resistivity, Mobility and Impurity Levels in GaAs, Ge, and Si at $300^{\circ} \mathrm{K}$, Solid-State Electron. 11 (1968) 599-602.

[11] M. A. Green, Solar Cells, Prentice-Hall, 1982.

[12] A. Luque, S. Hegedus, Handbook of Photovoltaic Science and Engineering, Wiley \& Sons, 2003.

[13] C. S. Fuller, J. D. Struthers, J. A. Ditzenberger, K. B. Wolfstirn, Diffusivity and Solubility of Copper in Germanium, Phys. Rev. 93 (1954) 1182-1190.

[14] C. S. Fuller, J. C. Severiens, Mobility of Impurity Ions in Germanium and Silicon, Phys. Rev. 96 (1954) 21-25. 
[15] W. C. Dash, Copper Precipitation on Dislocations in Silicon, J. Appl. Phys. 27 (1956) 1193-1195.

[16] F. C. Frank, D. Turnbull, Mechanism of Diffusion of Copper in Germanium, Phys. Rev. 104 (1956) 617-618.

[17] A. G. Tweet, C. J. Gallagher, Structure Sensitivity of Cu Diffusion in Ge, Phys. Rev. 103 (1956) 828.

[18] A. G. Tweet, Precipitation of Cu in Ge, Phys. Rev. 16 (1957) 221-224.

[19] C. J. Gallagher, Electrolysis of Copper in Solid Silicon, J. Phys. Chem. Solids 3 (1957) 82-86.

[20] H. H. Woodbury, W. W. Tyler, Triple Acceptors in Germanium, Phys. Rev. 105 (1957) $84-92$.

[21] C. S. Fuller, J. M. Whelan, Diffusion, solubility, and electrical behavior of Copper in Gallium Arsenide, J. Phys. Chem. Solids 6 (1958) 173-177.

[22] A. G. Tweet, W. W. Tyler, Enhanced $\mathrm{Cu}$ Concentration in Ge Containing Ni at $500^{\circ} \mathrm{C}, \mathrm{J}$. Appl. Phys. 29 (1958) 1578-1580.

[23] A. G. Tweet, Precipitation of Cu in Ge. II. Supersaturation Effects, Phys. Rev. 111 (1958) $57-66$.

[24] J. M. Whelan, C. S. Fuller, Precipitation of Copper in Gallium Arsenide, J. Appl. Phys. 31 (1960) 1507-1508.

[25] R. N. Hall, J. H. Racette, Diffusion and Solubility of Copper in Extrinsic and Intrinsic Germanium, Silicon and Gallium Arsenide, J. Appl. Phys. 35 (1964) 379-397.

[26] J. Blanc, L. R. Weisberg, Electrical Activity of Copper in GaAs, J. Phys. Chem. Solids 25 (1964) 221-223.

[27] C. S. Fuller, K. B. Wolfstirn, H. W. Allison, Defects in GaAs Produces by Copper, Appl. Phys. Lett. 4 (1964) 48-49.

[28] C. S. Fuller, K. B. Wolfstirn, H. W. Allison, Defect Centers in GaAs produced by $\mathrm{Cu}$ diffusion, J. Appl. Phys. 38 (1967) 4339-4345.

[29] C. S. Fuller, K. B. Wolfstirn, H. W. Allison, Hall-Effect Levels Produced in Te-Doped GaAs Crystals By Cu Diffusion, J. Appl. Phys. 38 (1967) 2873-2879.

[30] H. J. Queisser, C. S. Fuller, Photoluminescence of Cu-Doped Gallium Arsenide, J. Appl. Phys. 37 (1966) 4895-4899.

[31] J. R. Davis Jr., A. Rohatgi, R. H. Hopkins, P. D. Blais, P. Rai-Choudhury, J. R. McCormick, H. C. Mollenkopf, Impurities in Silicon Solar Cells, IEEE Trans. Electron Devices 27 (1980) 677-687.

[32] A. Rohatgi, J. R. Davis Jr., R. H. Hopkins, P. Rai-Choundhury, P. G. McMullin, J. R. McCormick, Effect of Titanium, Copper and Iron on Silicon Solar Cells, Solid-State Electron. 23 (1980) 415-422. 
[33] G. Coletti, P. C. P. Bronsveld, G. Hahn, W. Warta, D. Macdonald, B. Ceccarolo, K. Wambach, N. L. Quang, J. M. Fernandez, Impact of Metal Contamination in Silicon Solar Cells, Adv. Funct. Mater. 21 (2011) 879-890.

[34] F. Hasegawa, Different diffusion behavior of copper in epitaxial and in bulk GaAs, J. Appl. Phys. 45 (1974) 1944-1947.

[35] C. Brandt, C. Baur, A. Caon, P. Müller-Buschbaum, C. Zimmermann, T. Andreev, The Influence of High Temperatures on Radiation Damage of $\mathrm{GaInP}_{2} / \mathrm{GaAs} / \mathrm{Ge}$ Triple Junction Cells, IEEE J. Photovolt. 3 (2013) 904-908.

[36] R. L. Crabb, Solar Cell Radiation Damage, Radiat. Phys. Chem. 43 (1994) 93-103.

[37] N. Núñez, J. R. González, M. Vázquez, C. Algora, P. Espinet, Evaluation of the reliability of high concentrator GaAs solar cells by means of temperature accelerated aging tests, Prog. Photovolt. Res. Appl. 21 (2013) 1104-1113.

[38] ESA-ESTEC Requirements \& Standards Division, ECSS-E-ST-20-08C, Space Engineering: Photovoltaic assemblies and components (2012).

[39] M.-A. Nicolet, Diffusion barriers in thin films, Thin Solid Films 52 (1978) 415-443.

[40] J. Kang, J. You, C. Kang, J. J. Pak, D. Kim, Investigation of Cu metallization for Si solar cells, Sol. Energy Mater. Sol. Cells 74 (2002) 91-96.

[41] K. D. H., S. H. Lee, Investigation on Plated Ni/Cu Contact for Mono-Crystalline Silicon Solar Cells, Electron. Mater. Lett. 9 (2014) 677-681.

[42] S. K. Min, D. H. Kim, S. H. Lee, Nickel Silicide for Ni/Cu Contact Mono-Silicon Solar Cells, Electron. Mater. Lett. 9 (2013) 433-435.

[43] A. Mondon, M. N. Jawaid, J. Bartsch, M. Glatthaar, S. W. Glunz, Microstructure analysis of the interface situation and adhesion of thermally formed nickel silicide for plated nickelcopper contacts on silicon solar cells, Sol. Energy Mater. Sol. Cells 117 (2013) 209-213.

[44] A. Mondon, J. Bartscj, M. Kamp, A. Brand, B. Steinhauser, N. Bay, J. Horzel, M. Glatthaar, S. W. Glunz, Plated nickel-copper contacts on c-Si: from microelectronic processing to cost effective silicon solar cell production, in: Proceedings of the 29th European PV Solar Energy Conference, 2014.

[45] I. Rey-Stolle, B. Galiana, C. Algora, Assessment of a low-cost gold-free metallization for III-V high concentrator solar cells, Sol. Energy Mater. Sol. Cells 91 (2007) 847-850.

[46] C.-H. Hsu, E. Y. Chang, H.-J. Chang, H. Yu, H. Q. Nguyen, J.-S. Maa, K. Pande, Gold-Free Fully Cu-Metallized InGaP/InGaAs/Ge Triple-Junction Solar Cells, IEEE Electron Device Lett. 35 (2014) 1275-1277. 


\begin{tabular}{l|lllll}
$\mathrm{E}_{\mathrm{act}}=0.70 \mathrm{eV}$ & $200^{\circ} \mathrm{C}$ & $250^{\circ} \mathrm{C}$ & $300^{\circ} \mathrm{C}$ & $350^{\circ} \mathrm{C}$ & $400^{\circ} \mathrm{C}$ \\
\hline GEO & 8.5 days & 2.0 days & 10.0 hours & 3.5 hours & 1.5 hours \\
LEO & 37.0 days & 7.5 days & 2.0 days & 14.5 hours & 6.0 hours \\
Extreme & 55.0 days & 11.0 days & 3.0 days & 21.5 hours & 8.0 hours
\end{tabular}

\begin{tabular}{l|lllll}
$\mathrm{E}_{\text {act }}=1.02 \mathrm{eV}$ & $200^{\circ} \mathrm{C}$ & $250^{\circ} \mathrm{C}$ & $300^{\circ} \mathrm{C}$ & $350^{\circ} \mathrm{C}$ & $400^{\circ} \mathrm{C}$ \\
\hline GEO & 10.0 hours & 55.0 minutes & 8.0 minutes & 1.5 minutes & 22.0 seconds \\
LEO & 4.5 days & 10.0 hours & 1.5 hours & 15.5 minutes & 4.0 minutes \\
Extreme & 7.0 days & 15.0 hours & 2.5 hours & 23.5 minutes & 6.0 minutes
\end{tabular}

Table 1: Accelerated test times at various accelerated test temperatures for GEO (15 years, $\left.70^{\circ} \mathrm{C}\right)$ and LEO $(10$ years, $100^{\circ} \mathrm{C}$ ) missions and for an extreme scenario $\left(15\right.$ years, $100^{\circ} \mathrm{C}$ ) for activation energies of $0.70 \mathrm{eV}$ and $1.02 \mathrm{eV}$. Values are presented in days if larger than 24 hours, in minutes if smaller than one hour and in seconds if smaller than one minute. All values were rounded off towards the next 0.5 second $/ \mathrm{minute} / \mathrm{hour} /$ day so the test time is always overestimated.

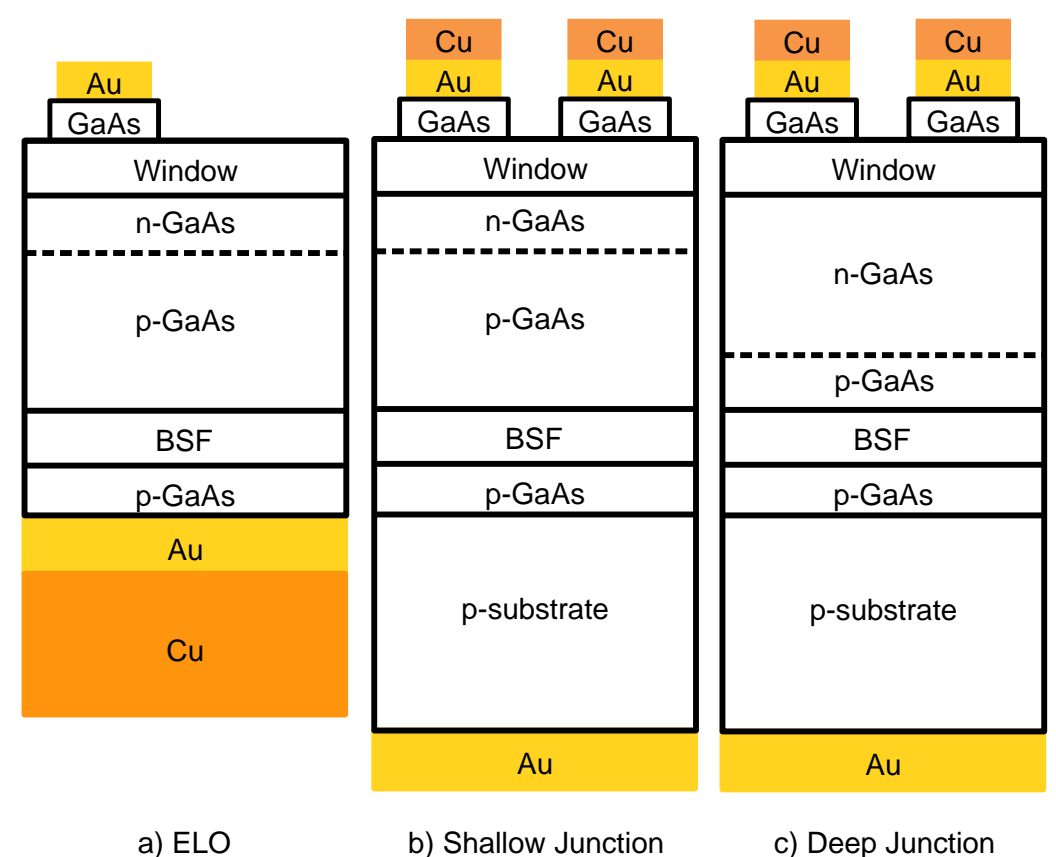

Figure 1: Schematic representations of the cell structures of a) an ELO GaAs solar cell b) a shallow junction substrate GaAs solar cell with $\mathrm{Cu}$ on the front contacts and c) a deep junction substrate GaAs solar cell with $\mathrm{Cu}$ on the front contacts. 


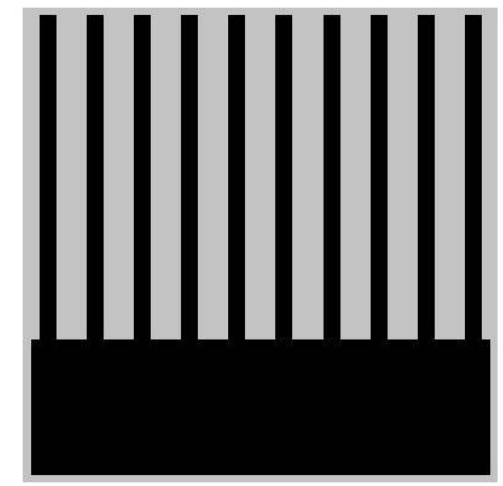

Figure 2: Schematic representation of the front contact grid pattern, the grey square indicates the total solar cell surface area.

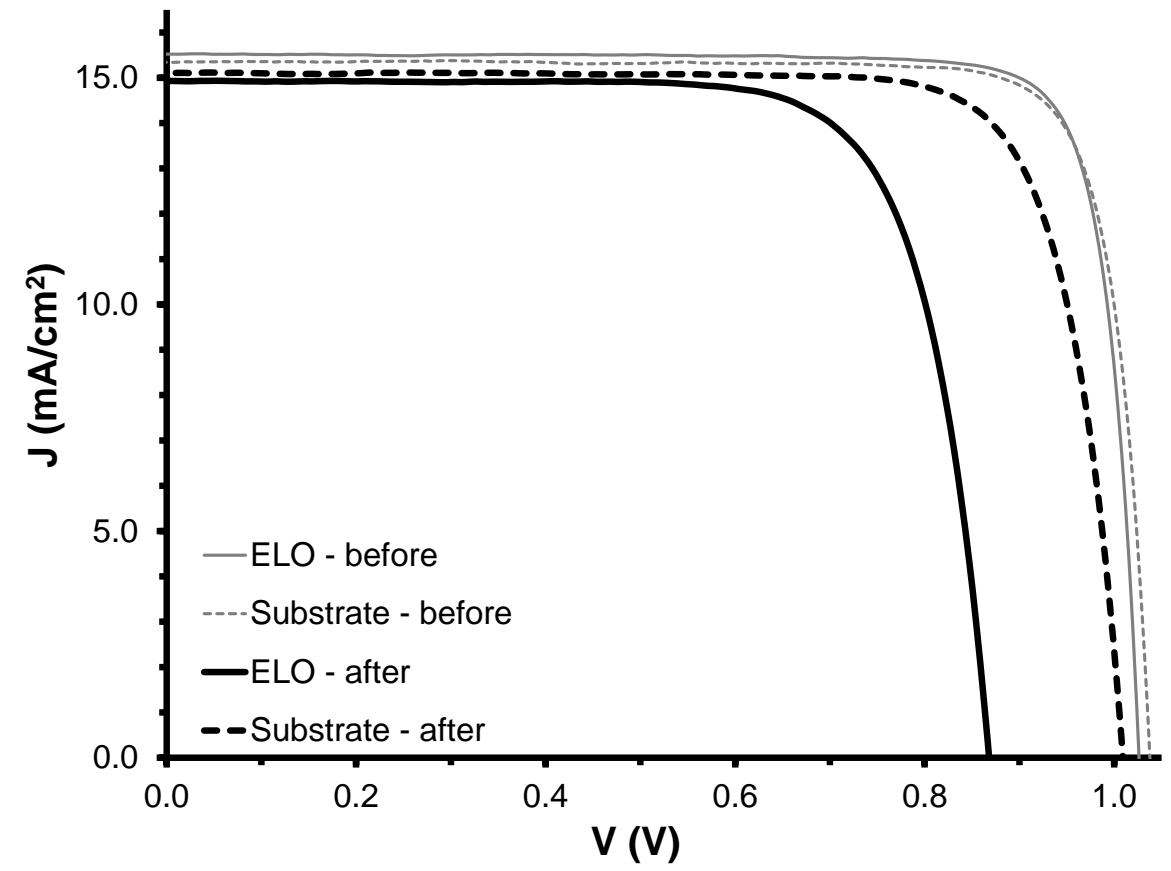

Figure 3: J-V curves of Au ELO and substrate solar cells before and after annealing for 4 hours at $300^{\circ} \mathrm{C}$. 

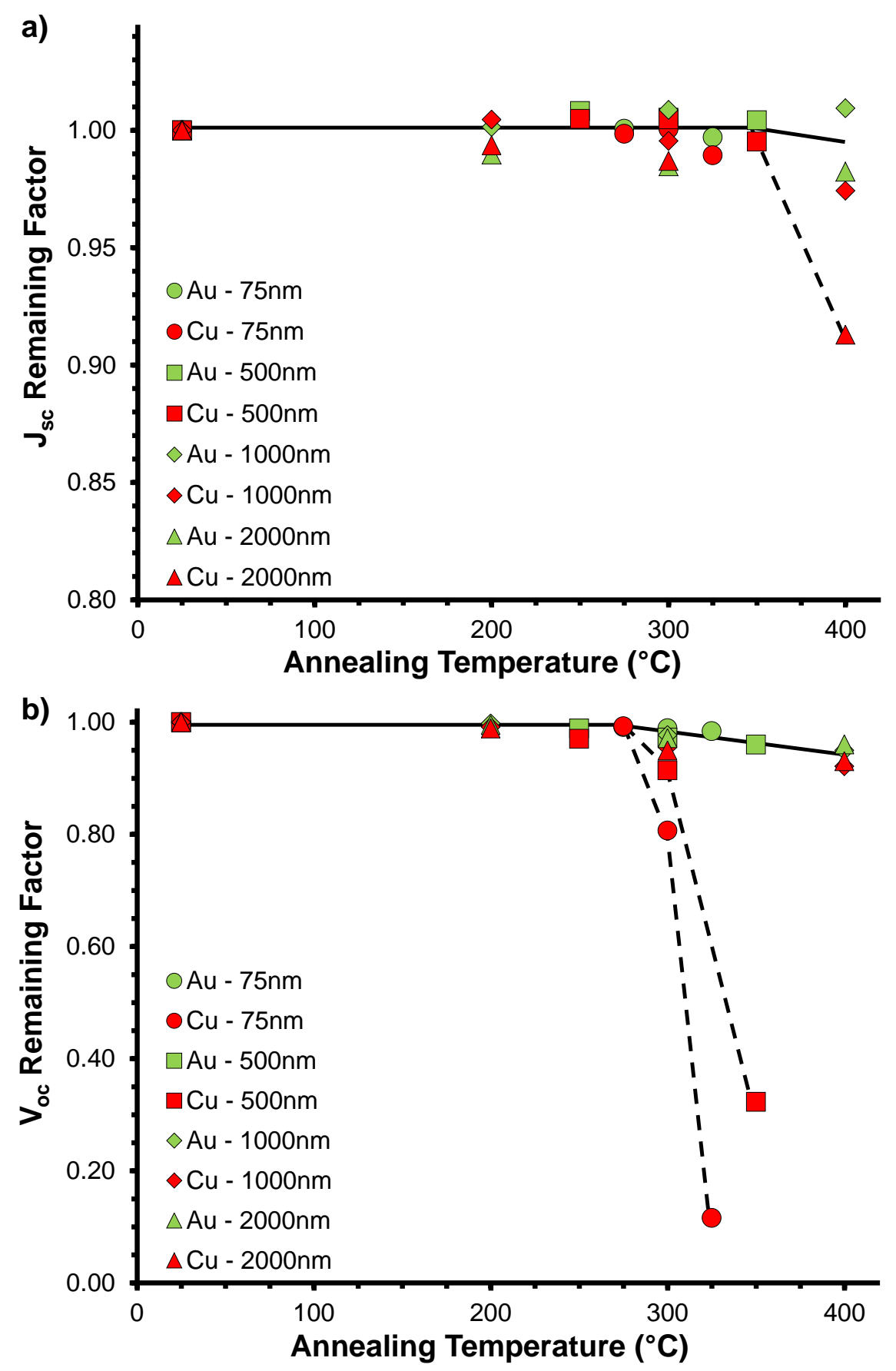

Figure 4: The average value of the remaining factor of a) $\mathrm{J}_{\mathrm{sc}}$ and $\mathrm{b}$ ) $\mathrm{V}_{\mathrm{oc}}$ for $\mathrm{Au}$ and $\mathrm{Cu}$ cells plotted against annealing temperature for junction depths of $75 \mathrm{~nm}, 500 \mathrm{~nm}, 1000 \mathrm{~nm}$ and $2000 \mathrm{~nm}$. The solid line displays the general trend, the dashed lines highlight the most notable deviations. 


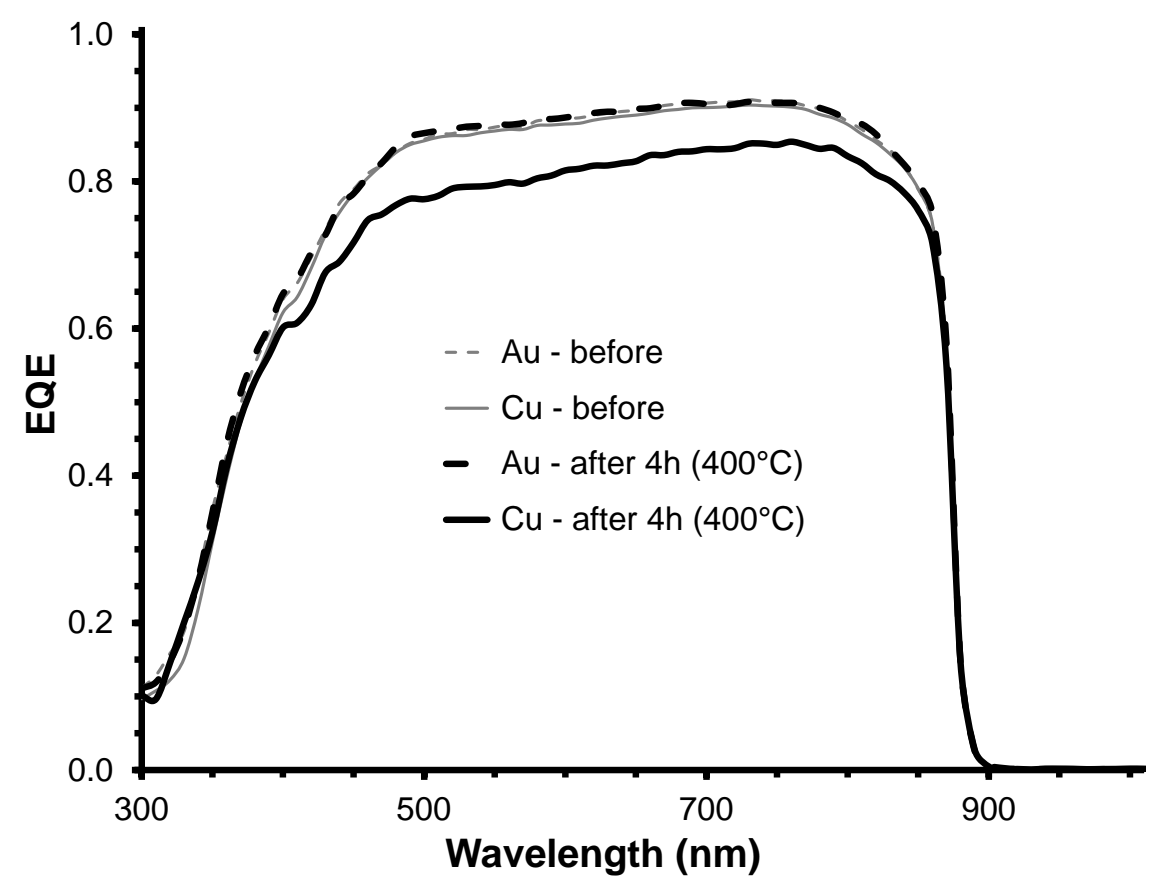

Figure 5: External quantum efficiency curves of a 2000nm deep junction Au cell and a 2000nm deep junction Cu cell before and after annealing for $4 \mathrm{~h}$ at $400^{\circ} \mathrm{C}$.

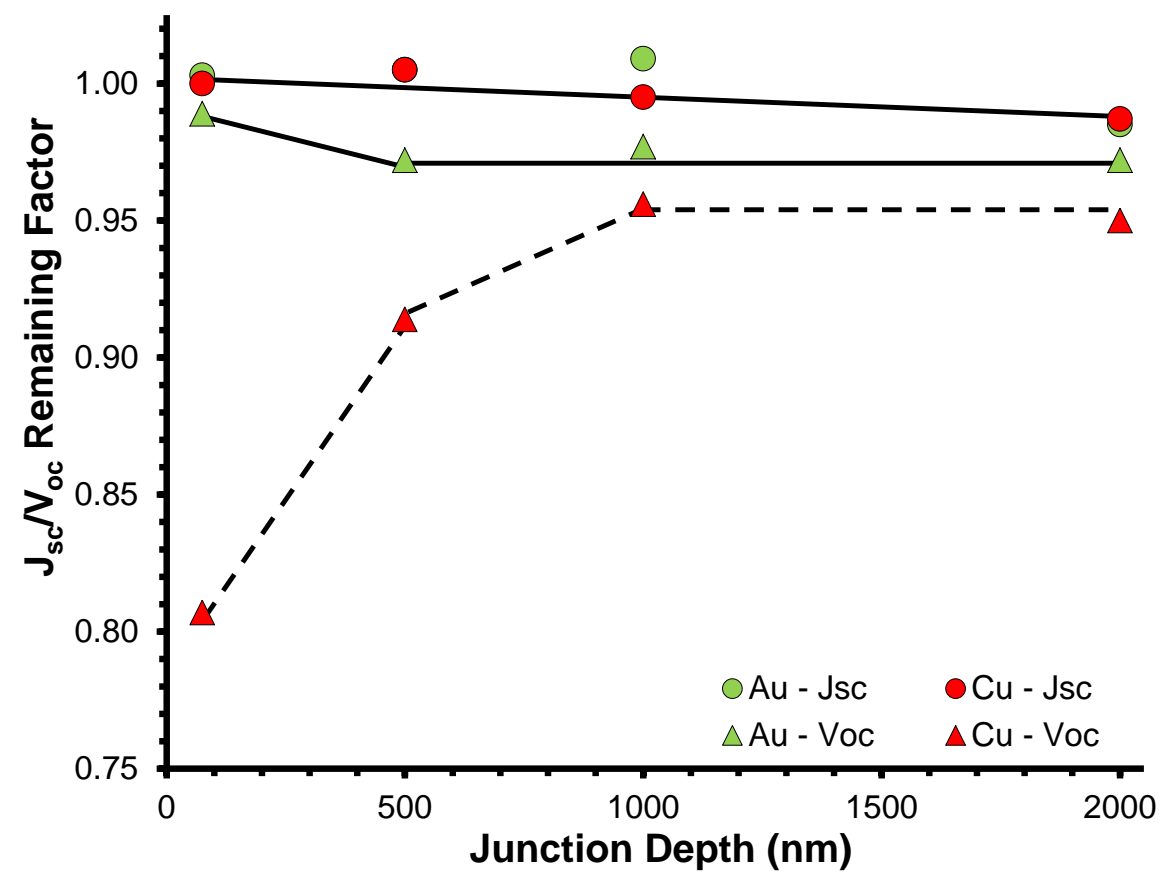

Figure 6: The average value of $\mathrm{J}_{\mathrm{Sc}}$ and $\mathrm{V}_{\mathrm{oc}}$ remaining factors of $\mathrm{Au}$ and $\mathrm{Cu}$ cells plotted against junction depth for annealing for 4 hours at $300^{\circ} \mathrm{C}$., dashed lines indicate the most notable features. 


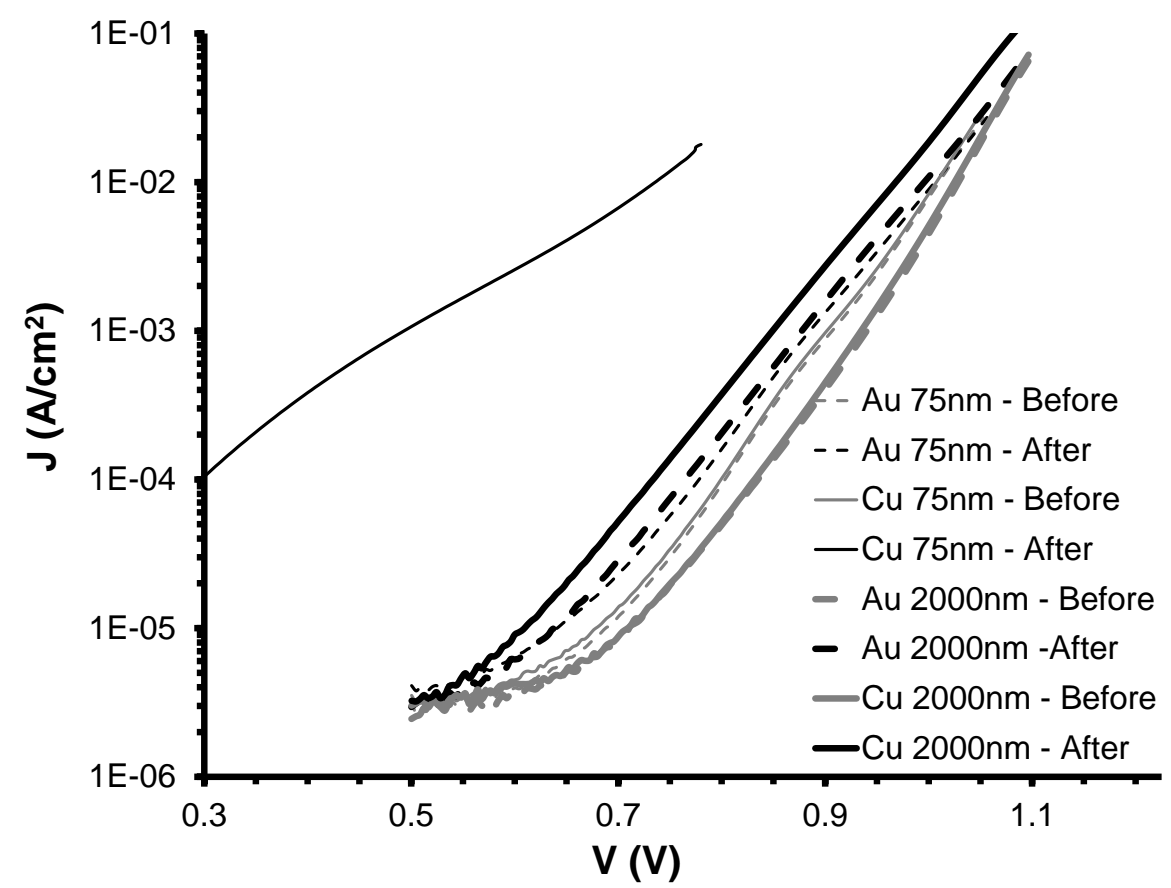

Figure 7: Dark J-V curves of a $75 \mathrm{~nm}$ shallow junction Au cell, $75 \mathrm{~nm}$ shallow junction Cu cell, 2000nm deep junction $\mathrm{Au}$ cell and a $2000 \mathrm{~nm}$ deep junction $\mathrm{Cu}$ cell before and after annealing at $300^{\circ} \mathrm{C}$ for $4 \mathrm{~h}$.

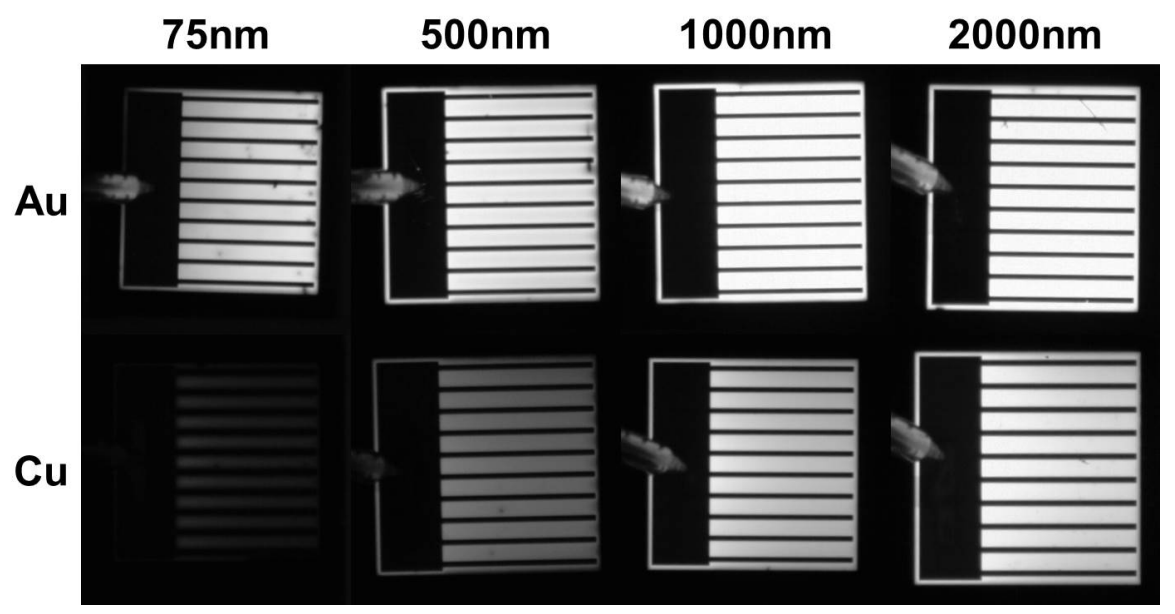

Figure 8: Infra-red electroluminescence images of $\mathrm{Au}$ and $\mathrm{Cu}$ substrate solar cells annealed for $4 \mathrm{~h}$ at $300^{\circ} \mathrm{C}$ for junction depths of 75,500, 1000 and 2000nm. Experimental conditions were the same for all images. 

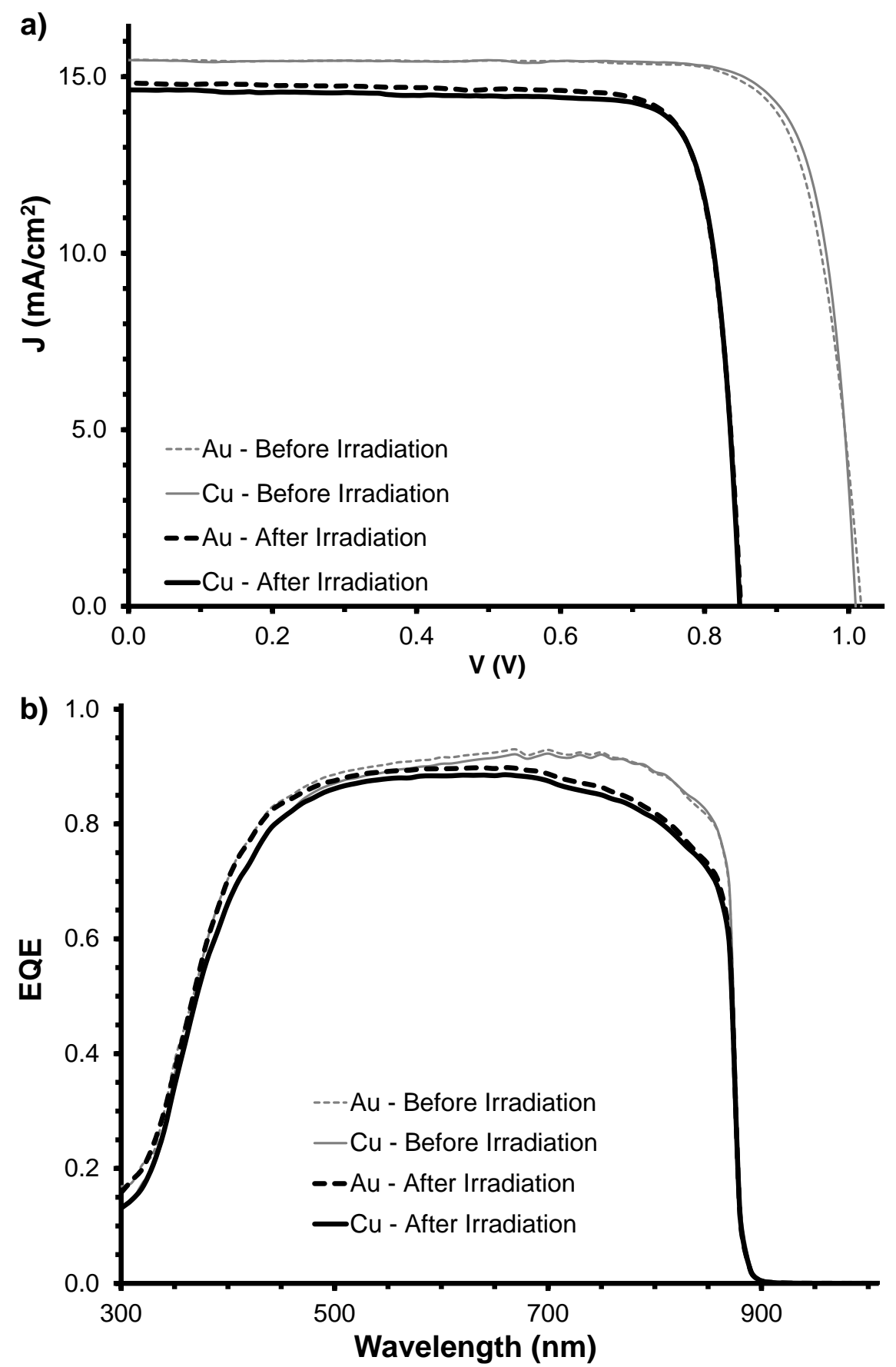

Figure 9: J-V curves a) and EQE curves b) of an Au and a Cu cell with a junction depth of $75 \mathrm{~nm}$ before and after irradiation with a $1 \mathrm{MeV}$ electron irradiation dose of $10^{15} \mathrm{e}^{-} / \mathrm{cm}^{2}$. 

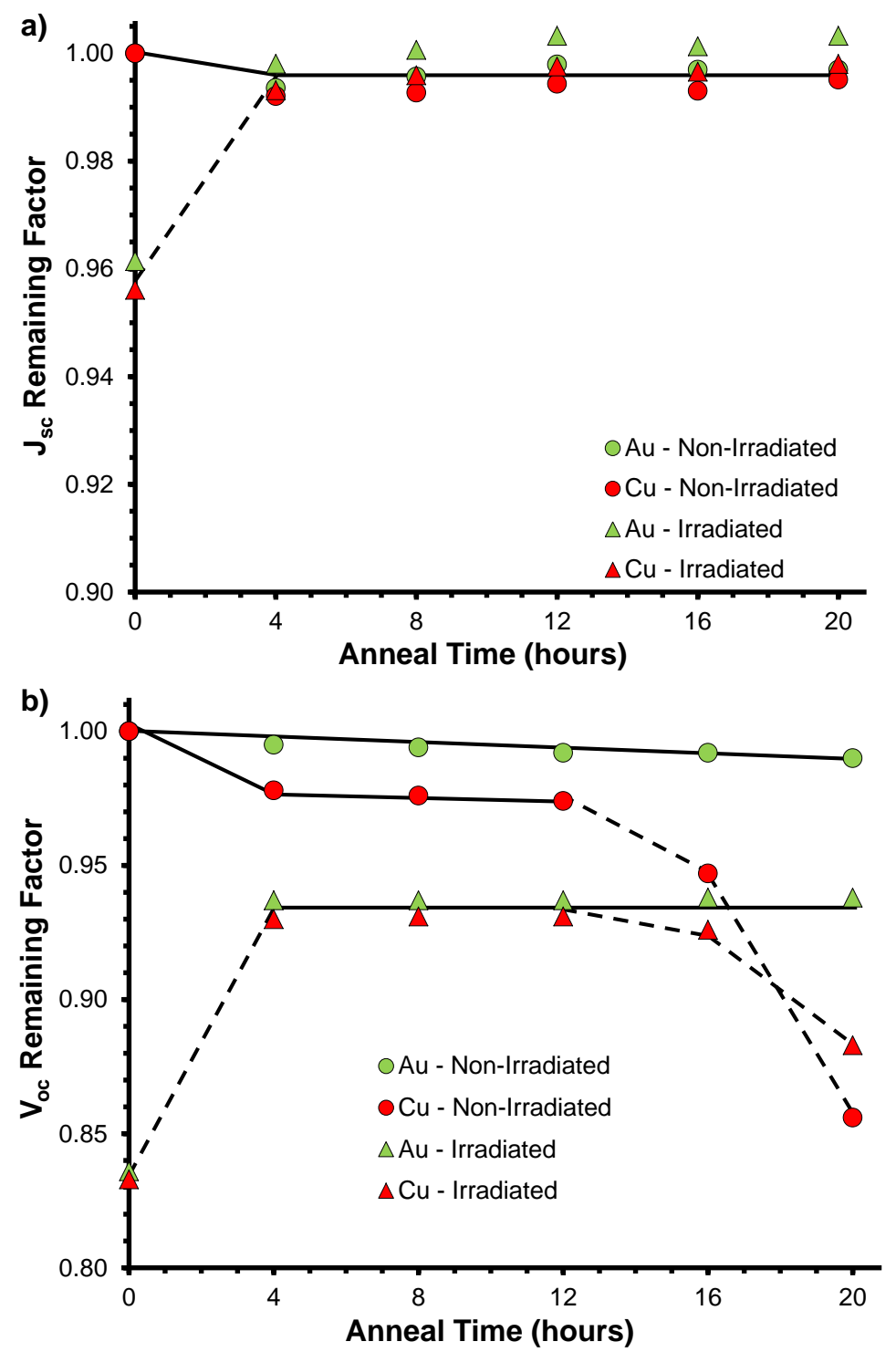

Figure 10: The average remaining factor of a) $\mathrm{J}_{\mathrm{sc}}$ and b) $\mathrm{V}_{\mathrm{oc}}$ of non electron irradiated and electron irradiated $\mathrm{Au}$ and $\mathrm{Cu}$ cells with $75 \mathrm{~nm}$ junction depth plotted versus the annealing time at $275^{\circ} \mathrm{C}$. The electron irradiation dose was $10^{15} \mathrm{e}^{-} / \mathrm{cm}^{2}$ of $1 \mathrm{MeV}$ electrons. The lines are a guide to the eye, dashed lines indicate the most notable features. 